\title{
Only five doctors in Canada can assess mental status for US Customs and Border Protection
}

$\mathrm{S}$ omething as simple as a bottle of antidepressants in a passenger's carry-on luggage can trigger questions from US Customs and Border Protection officials that result in the denial of entry to the United States or the need for medical clearance.

Every month, US border agents prohibit a handful of Canadians from entering the United States because of a health issue - one of the 60 grounds for denial of entry listed in the US Immigration and Naturalization Act. When people are denied entry, Customs and Border Protection officials advise them to make an appointment with one of only five "panel physicians" in Canada that the US government has hired to perform physicals and provide medical clearances.

That's what happened to Ellen Richardson on Nov. 25. US officials at Toronto Pearson International Airport in Ontario, fingerprinted Richardson and ran her name through the Canadian Police Information Centre (CPIC), a national police database managed by the
RCMP. The database contained information about a 911 call made to police in 2012, when Richardson was suffering from depression and experienced an episode that resulted in hospitalization.

When she was refused entry to the US, a border official told Richardson she could visit one of three family doctors in the Toronto area to provide a let-
Ontario, one of the three doctors in the Toronto area who can provide medical clearances for the US government.

"If they have a feeling that the person has some psychiatric history and is not stable, they can't assess them so they say 'Look - get medical clearance from one of these panel physicians," Zatzman explains.

\section{About three people are turned back from Toronto's airport every month.}

ter assuring them that she was not a danger to herself or others. The other two US-approved panel physicians are in Surrey, British Columbia, and Montréal, Quebec.

The half-hour medical appointment costs $\$ 500$ - a hefty addition to any vacation or business trip south of the border.

The border officials have no medical training, "so they can't really assess people," says Dr. Ian Zatzman of Vaughan,

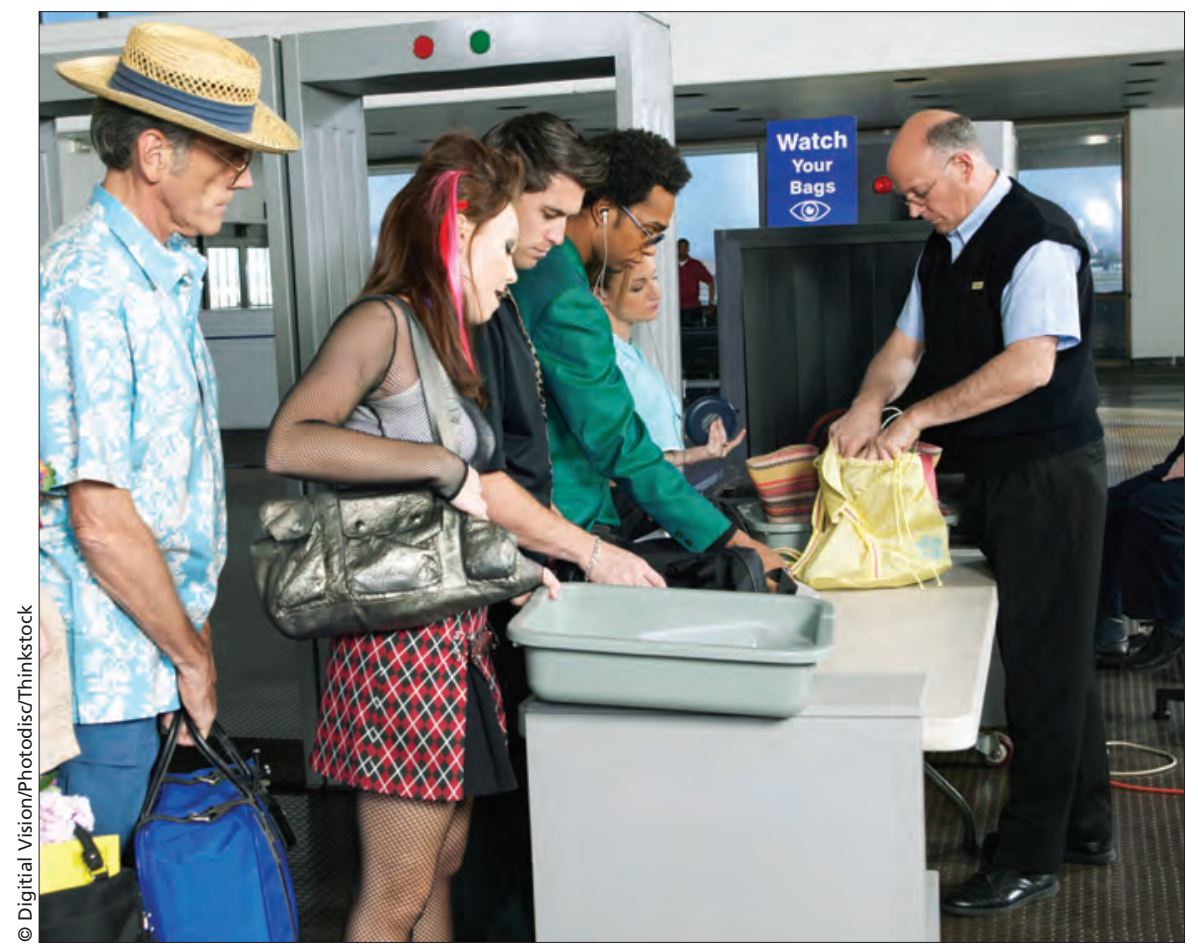

Something as simple as a bottle of antidepressants in a passenger's carry-on luggage can trigger questions from US Customs and Border Protection officials that result in the denial of entry to the United States or the need for medical clearance.
About three people are turned back from Toronto Pearson International Airport every month, and Zatzman has assessed several of them. When people arrive for an assessment, they have to bring a letter from their doctor, their medical history, any police records and the document that US Customs and Border Protection gave them when they were denied entry. The doctors review the documents as well as interview the individual.

The border officials do not have access to any medical records, Zatzman stresses - simply to whatever information police received when they responded to an emergency call.

"Very often, these police records are absolutely wrong as to what was happening medically," he says.

Whatever is on the CPIC database "is not a medical diagnosis," he stresses. "Most of the time we clear people because they really aren't dangerous."

Although US officials asked Zatzman and the other physicians it hires not to talk to the media, he felt it was important to clarify through $C M A J$ that the border officials do not have anyone's actual medical records, he says.

"People may think that's somehow sharing medical information, but if it's not coming from a doctor or a hospital, it's not medical information - it's the police interpretation of what happened," he says. - Laura Eggertson, Ottawa, Ont.

CMAJ 2014. DOI:10.1503/cmaj.109-4685 